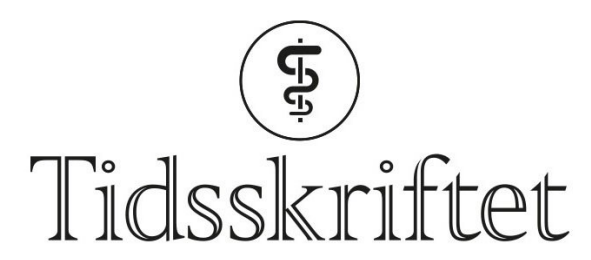

DEN NORSKE LEGEFORENING

\title{
Et barn er født
}

MINILEDER

ARE BREAN

Sjefredaktør

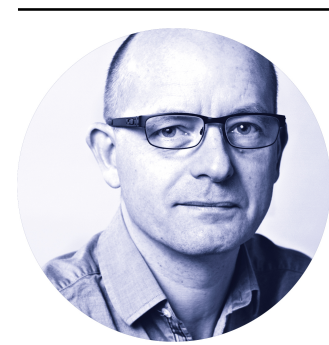

I løpet av 2018 vil det fødes om lag 140 millioner barn på kloden. Hvert eneste av dem er et helt unikt individ, som vil bli ulikt alle de andre barna som noensinne er født på jorden. At vi alle er så like, og samtidig helt unike, er et av klodens aller største undere.

Men to av dette årets barnekull er enda litt mer unike enn de andre. Lulu og Nana er født på et hemmelig sted i Kina. Om vi skal tro de første meldingene om dem, er de de første mennesker som har et CRISPR-redigert genmateriale. Endringene som er gjort i arvemassen, er ikke store: Det er satt inn ekstra kopier av en genvariant som gir immunitet mot hiv. Denne varianten vil de føre videre til sine barn og sine barns barn igjen - i prinsippet så lenge deres etterkommere lever.

Forskeren som har gjort dette, He Jianku, mottok voldsom kritikk, både på kongressen der fødselen ble offentliggjort 27. november, og senere verden over. Det er forståelig - de etiske problemene står i lang, lang kø. Muligheten for utilsiktede genendringer er bare ett av dem. Det er ikke uten grunn at genforskere verden over har bestemt seg for ikke å bruke CRISPRverktøyet til å gjøre endringer som arves.

Men enten man vil utsi dommedagsprofetier over hva som nå kan skje eller glede seg over muligheten til å redigere sykdomsgener, er det bare én ting å si til Lulu og Nana: Velkommen blant oss andre unike og like, begge to!

Publisert: 10. desember 2018. Tidsskr Nor Legeforen. DOI: 10.4045/tidsskr.18.20.01

(C) Tidsskrift for Den norske legeforening 2020. Lastet ned fra tidsskriftet.no 